\title{
マシニングセンタの円弧補間運動における二山象限突起の補正*
}

\author{
樋口 拓郎 ${ }^{* 1}$, 国貞 宏通 ${ }^{* 2}$, 国井 嘉仁 ${ }^{* 3}$, 佐藤 隆太 ${ }^{* 4}$, 堤 正臣 $^{* 5}$
}

\section{Compensation of Quadrant Glitches with Two Peaks in Circular Motions of Machining Centers}

\author{
Takuro HIGUCHI, Hiromichi KUNISADA, Yoshinori KUNII, \\ Ryuta SATO and Masaomi TSUTSUMI ${ }^{* 5}$
}

\author{
${ }^{* 5}$ Tokyo University of Agriculture and Technology, Dept. of Mechanical Systems Engineering \\ 2-24-16 Nakacho, Koganei, Tokyo 184-8588 Japan
}

Quadrant glitches are one of the causes of deteriorating the machining accuracy in NC machine tools because those leave streaky marks on the machined surfaces. The quadrant glitch is caused by friction of the ball screw and linear guides of feed drive systems. In this study, when the circular trajectories are precisely investigated by conducting the circular motions under various conditions, it is found that the preload in the ball screw affects the height and shape quadrant glitches at low feed speed. It is caused by the difference of contact points between balls and grooves of ball screws. It is also found that the quadrant glitch becomes one peak in case of oversize preload in ball screw, and two peaks in case of offset preload. In this study, a method for compensating two peaks observed in quadrant glitches due to the change of contact points between balls and grooves of a ball screw is proposed. A proposed compensating method can cancel the friction torque changes generated in the ball screws with a new mathematical model. It is confirmed that the proposed method can decrease the quadrant glitches in a wide feed speed range through simulation and experiment, and the proposed method can correct two peaks of the quadrant glitches in high accuracy. In addition, from circular motions with mass, it is confirmed that the proposed method can correct the quadrant glitches without deteriorating effect of mass.

Key Words : Machining Center, Circular Motion, Quadrant Glitch, Ball Screw, Offset Preload, Oversized Ball

\section{1. 緒言}

NC 工作機械は，複数の送り駆動機構を同時制御することによって，工具と工作物とを相対運動させ，任意の 形状を作り出すことかできる，そのため，送り駆動機構の運動精度は加工精度として工作物に転写される．近年 では工業製品の精密化に伴って NC 工作機械には高速かつ高精度な加工が求められており，送り駆動機構の運動 精度の向上は重要な課題とされてきた．現在では，NC 工作機械の加工時に必要な剛性を確保するため，送り駆 動機構にボールねじが広く採用されている.しかし, ボールねじを使った送り駆動機構では, 駆動機構内に大き な摩擦力が生じるため, 直進 2 軸の同時制御で円運動 ${ }^{(1)}$ 行うと, 各軸の運動方向反転時の摩擦力変化に起因し て円運動軌跡に突起状の誤差 ${ }^{(2)}$ が発生する。この突起状の誤差は，象限突起と呼ばれ，運動精度を低下させる大 きな要因の一つとされている. 実際に象限突起の発生によって加工面に筋状の跡が残るため, 象限突起は NC 工 作機械の高速化や高精度化にとって解決すべき問題とされてきた.

これまでに象限突起の補正に関する研究が盛んに行われており ${ }^{(3)}(13)$, 様々な象限突起の補正方法が提案されて

\footnotetext{
* 原稿受付 2011 年 11 月 11 日

*1 正員, 東京農工大学院生物システム応用科学府（テ184-8588 東京都小金井市中町 2-24-16）

*2 東京農工大学院生物システム応用科学府

*3 東京農工大学院工学府

*4 正員, 神戸大学工学研究科（广657-8501 兵庫県神戸市灘区六甲台町 1-1）

*5 正員, フェロー, 東京農工大学大学院工学究院（テ184-8588 東京都小金井市中町 2-24-16）

E-mail: tsutsumi@cc.tuat.ac.jp
} 
いる. それらの象限突起の補正方法には, 外乱オブザーバのような状態推定形の補償と, 数学モデルに基づいた フィードフォワード補償との 2 種に大別される. 特に, 後者のフィードフォワード補償は, 駆動機構の摩擦特性 に重点を置くことによって状態推定形補償よりも高精度な象限突起の補正を実現できることから, 数学モデルと

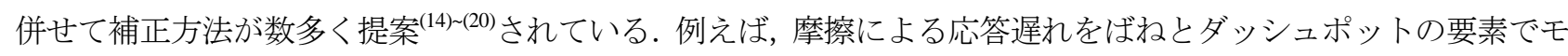

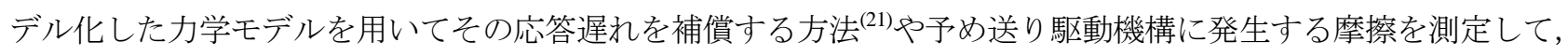
その摩擦の大きさに応じて同定した摩擦モデルから計算される補償值をトルク指令に印加することで摩擦力の影 響を打ち消して運動軌跡を補正する方法(22)，発見的自己組織化法を用いてサーボ情報から自律的にモデリングし た多項式の摩擦モデルによって速度指令を補正して摩擦を補償する方法(23)などが実施されている.

このように提案されている補正方法には, 数学モデルを構築するために, 象限突起の発生メカニズム(24) (27)を的 確に把握することが必要とされていた，それに加え，象限突起は摩擦力変化に起因して発生することから，ボー ルねじなどの機械要素の変化によって送り駆動機構の摩擦特性が変化し, 象限突起の形状も変化してしまう. 実 際に，オーバサイズボール予圧方式とダブルナット予圧方式との異なる 2 種類のボールねじを使った送り駆動機 構について, それぞれのボールねじで摩擦特性が異なることが確認されており ${ }^{(28)}$, さらに象限突起の形状が変化 することも確認されている(29).

本論文においても，送り駆動機構にオーバサイズボール予圧方式のボールねじと，ダブルナット予圧方式と同 様の構造であるオフセット予圧方式のボールねじとをそれぞれ搭載して円運動を実施して，ボールねじの予圧方 式における摩擦特性や象限突起への影響を調査した，その結果，それぞれの予圧方式で摩擦特性が異なることが 確認でき, オーバサイズボール予圧方式では象限突起が 1 山, オフセット予圧方式では 2 山の突起形状が形成さ れ，予圧方式によって象限突起の形状も変化することが確認できた．これらのことから，数学モデルを使って象 限突起を高精度に補正するためには, ボールねじの予圧方式に対応した補正方法が必要であることが考えられる. しかし，オーバサイズボール予圧方式に生じる 1 山の象限突起に対して数学モデルを使って補正した研究事例は あるものの, オフセット予圧方式に生じる 2 山の象限突起に対応した補正方法の研究事例は確認できなかった.

そこで，本論文では，送り駆動系の運動精度を制御系によって向上させることを目的とし，２山をもつ象限突 起の補正について検討した。 まず，ボールねじの予圧方式が象限突起に与える影響を調査し，オフセット予圧方 式のボールねじの摩擦特性に対応した数学モデルを考案して, 摩擦特性によって象限突起が 2 山になることをシ ミュレーションによって検証した，そこで，2 山の象限突起を補正するため，筆者らがすでに開発した摩擦補償 器 ${ }^{(2)}$ に着目し, 考案した数学モデルに基づいて摩擦の影響を打ち消寸補償器を提案した. その補償器の効果につ いて検討したところ，シミュレーションと実験の両方で，２山をもつ象限突起を高精度に補正できることが確認 できた。また，本論文で提案した補償器を実際のマシニングセンタの制御系に組み込んで実装し，実機において も 2 山の象限突起を高精度に補正できることがわかった，さらに，実機の送り速度や円運動位置が変化した場合 や，テーブルに負荷質量を積載した場合でも，提案した補償器によって 2 山の象限突起を補正できることを明ら かにしている.

\section{2. 実験装置}

本論文では，図 1 に示すように，実験装置として NC 工作機械の X 軸，Y 軸の送り駆動系を抽出した装置を用 いる.この実験装置は, $23 \pm 2^{\circ} \mathrm{C} に$ 空調された北側の部屋に据え付けられている. この装置の XY テーブルは, リ テーナ入り直動転がり案内によって案内されている.

この XY テーブルの X 軸と $\mathrm{Y}$ 軸は，それぞれ設計上で全く同じ構造となっており，それぞれがボールねじと AC サーボモータで構成されたボールねじ駆動である。これら $\mathrm{X}$ 軸, $\mathrm{Y}$ 軸それぞれの送り駆動機構は，オーバサ イズボール予圧方式またはオフセット予圧方式のボールねじを付け替えることができる，オーバサイズボール予 圧方式では，㸚じ軸とナットの溝の直径よりも大きな直径のボールを介在させることによって予圧を与えるボー ル対じであり, 㸚じ軸とナットの溝に対してボールが 4 点で接触する，オフセット予圧方式では，ねじ軸の溝の ピッチよりもナット溝のピッチを一部だけ大きくすることで, 軸方向にボールを押し付けて予圧を与えるボール ねじであり，ねじ軸とナットの溝に対してボールが 3 点で接触する。また， $\mathrm{X}$ 軸と $\mathrm{Y}$ 軸には，各軸のモータの端 に，モータ回転角 $\theta \quad[\mathrm{rad}]$ を検出するためのロータリエンコーダが取り付けられている. 
この装置の制御系は，DSP ボードを搭載した PC とサーボアンプによって構成され，DSP ボード内で位置制御 および速度制御が行われ，サーボアンプ内でトルク制御を行われている.この実験装置の X 軸と Y 軸それぞれを セミクローズドループ制御方式に設定しており，図 2 のブロック線図で示すように，位置制御には比例制御，速 度制御には比例・積分制御を用いている. そのため, 位置ループではモータ端に取り付けられた分解能 $0.0001^{\circ}$ のロータリエンコーダによる検出結果をボールねじ定数 $l / 2 \pi[\mathrm{m} / \mathrm{rad}]$ で換算して位置フィードバック信号とし， 速度ループではそのロータリエンコーダによる検出結果を数值微分して速度フィードバック信号としている．こ れらの制御ループは PC 上で実行され，PCからはトルク指令信号が出力される．このトルク指令信号をサーボア ンプに入力することで, サーボアンプで電流を制御し，AC サーボモータを駆動して，テーブルを運動させる. また，サーボアンプのアナログモニタ端子は $\mathrm{AD}$ 変換器に接続されており，モータ出力トルクも測定できる.

以上に示すように，実験装置では，X軸と Y 軸両方のテーブル変位，モータの回転角と回転速度，モータ出力 トルクを同時に測定でき，制御則や指令值，補償值など制御系を自由に設定することができる，なお，本論文で この実験装置を使った実験結果の全てはロータリエンコーダによる測定結果である.

さらに，本論文では実用上での補償器の実装効果を検証するため，直進 3 軸を有するマシニングセンタに補償 器を適用し，実機での 2 山の象限突起補正についても検討している。この実機は，実験装置と同様の送り駆動系

（図 2）となっており，ロータリエンコーダによる検出信号を数值処理して位置と速度のフィードバック信号と している．制御系も実験装置と同様にセミクローズドループ制御方式が採用されている．また，駆動機構の X 軸 と Y 軸にはオフセット予圧方式のボールねじがそれぞれ搭載されている，なお，実機での結果も全てロータリエ ンコーダによる測定結果である.

本論文では，実験装置とそのシミュレーションモデルを用いて補償器の開発とその効果について検討し，この マシニングセンタに基づいて開発した補償器の実装効果も検証している.

\section{3. 円運動軌跡に及ぼすボールねじの予圧方式の影響}

\section{$3 \cdot 1$ 象限突起形状に及ぼす影響}

本論文では，象限突起形状に及ぼすボールねじの予圧方式の影響を調べるため，実験装置の送り駆動機構に才 一バサイズボール予圧方式とオフセット予圧方式のボールねじをそれぞれ使用して，指令半径 $10 \mathrm{~mm}$, 送り速度 $1 \mathrm{~m} / \mathrm{min}$ の円運動を実施した. 図 3 に円運動軌跡の測定結果を示寸．図は，円運動軌跡の平均半径からなる円弧 を基準円とし，その基準円からの運動軌跡の誤差を拡大して表示している．また，Y 軸 $90^{\circ}$ の位置での象限突起 を拡大表示している，図によると，図(a)のオーバサイズボール予圧方式では円運動軌跡の象限突起に 1 山の突起 形状が現れ，図(b)のオフセット予圧方式では 2 山の突起形状が現れていることが確認できる.

この実験では，ボールねじ以外は同じ装置を用いて円運動を行っていることから，ボールねじの予圧方式に応 じて異なった象限突起形状が形成されたと考えられる．また，象限突起は各軸の運動方向反転時に生じる摩擦力 変化に起因して発生することから, 送り駆動機構はボールねじの予圧方式によって運動方向反転時に異なる摩擦 特性を示すことが推測できる.
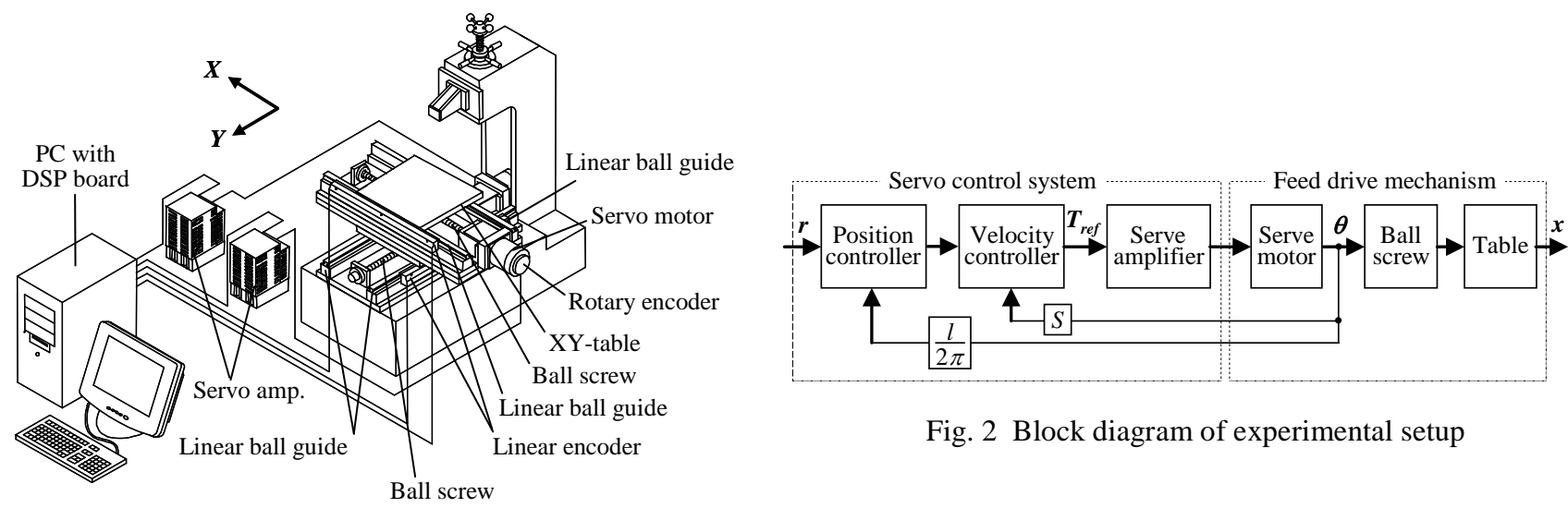

Fig. 2 Block diagram of experimental setup

Fig. 1 Schematic view of setup of XY table with servo system 


\section{$3 \cdot 2$ 摩擦特性に及ぼす影響}

そこで，ボールねじの予圧方式が駆動機構の摩擦特性に及ぼす影響を調べるため, 送り速度 $0.01 \mathrm{~m} / \mathrm{min}$, 指令 半径 $100 \mu \mathrm{m}$ として低速の円運動を実施した。このような低速の円運動では, 各軸の正弦波運動時の速度と加速 度の影響が小さくなることによって慣性力や粘性摩擦力が無視でき，モータトルクは駆動機構で生じる総摩擦卜 ルクと同等となることが考えられる，そこで，本論文では低速円運動時のモータトルクを摩擦トルクとして測定 し，テーブル変位における摩擦トルクから摩擦特性を観察している.

図 4 にテーブル変位と摩擦トルクの関係で示す. 図 4(a)によると, オーバサイズボール予圧での摩擦トルクは, 摩擦の非線形ばね特性によって 1 段のステップ状のヒステリシスループを描き, 軸の運動方向反転直後のテーブ ル変位が大きくなるにつれて摩擦トルクが収束している. しかし, 図 4(b)によると, オフセット予圧での摩擦卜 ルクは反転後に 2 段のステップをもつヒステリシスループとなっており，運動方向反転直後と反転位置から 100 $\mu \mathrm{m}$ の位置で摩擦トルクが大きく変化している.

以上のことから，ボールねじの予圧方式によって摩擦特性がそれぞれ異なり，オーバサイズボール予圧では運 動方向反転後に 1 段のステップ状，オフセット予圧では 2 段のステップ状の摩擦特性を示すことがわかった.

\section{$3 \cdot 3$ 方向反転時におけるボールの挙動}

このように，ボールねじの予圧方式によって摩擦特性が異なる原因は，運動方向が反転する際のボールとボー ルねじの溝との接触点数の変化によるものであると考えられる. オーバサイズボール予圧方式 $($ リード $l=10 \mathrm{~mm})$ とオフセット予圧方式（リード $l=16 \mathrm{~mm}$ ) との, ボールねじの溝とボールの一つ一つが全て同じ状態で接触して いると仮定すると，各予圧方式において送り駆動機構が往復運動したときのボールとねじ溝との接触状態は，図 5 のようになると推定できる. 図中の(1), (2), (3)はそれぞれ, 往復運動時の往路, 反転直後, 復路の状態である. 図 5(a)に示すように，オーバサイズボール予圧方式では，往路，反転直後，復路に関わらず，ボールねじの溝と ボールとの接触は終始 4 点のままである，そのため，運動方向が反転する際にも，ボールねじの溝とボールとの 摩擦抵抗が一様であり, オーバサイズボール予圧方式の摩擦特性は 1 段のステップ状を示したことが考えられる. これに対し，オフセット予圧方式では，図 5(b)に示すように，往路と復路においては溝とボールとが 3 点で接触 しているが，反転直後にボールねじの溝内をボールが移動することによって溝とボールとの接触点が一時的に 2 点になってしまう。さらに，反転後に同一方向へ運動し続けることによって溝内のボールも移動し続け，最終的 に溝とボールとの接触点が 3 点に変移する. そのため, オフセット予圧方式のボールねじでは, 運動方向反転の 際にボールねじの溝とボールとの接触点が 2 点から 3 点に変化することによって溝とボールとの摩擦抵抗が変化

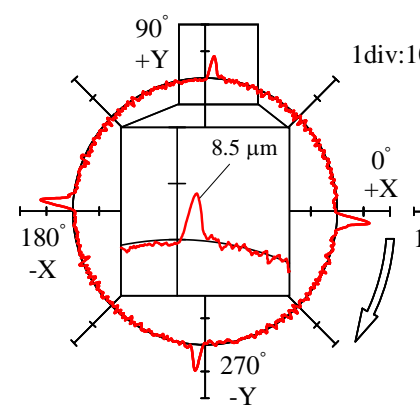

(a) Oversized ball preload

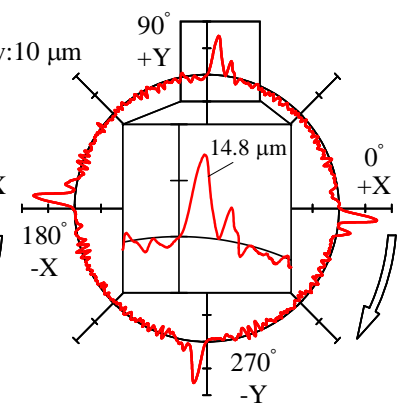

(b) Offset preload

Fig. 3 Measurement results of circular motions (radius: $10 \mathrm{~mm}$, feed rate: $1 \mathrm{~m} / \mathrm{min}$ )

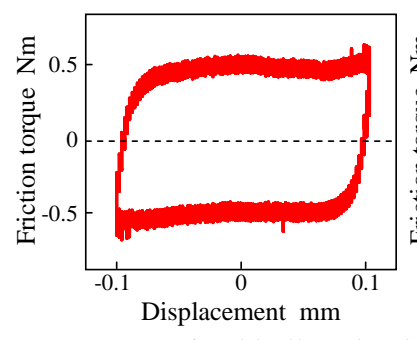

(a) Oversized ball preload

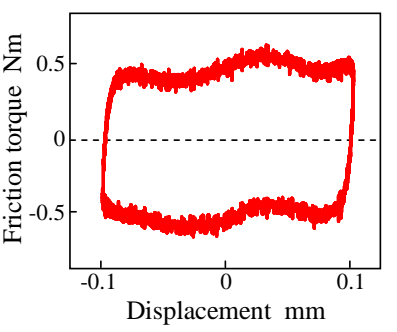

(b) Offset preload

Fig. 4 Relationship between measured friction torque and displacement

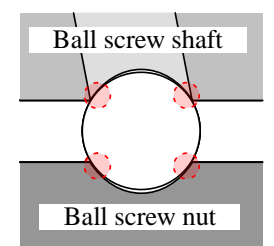

(1) Forward

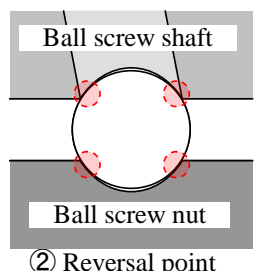

a) Oversized ball preload

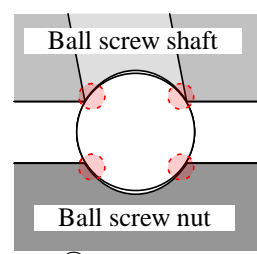

(3) Backward

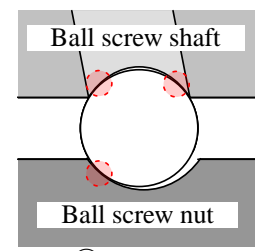

(1) Forward

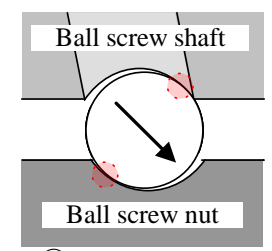

(2) Reversal point

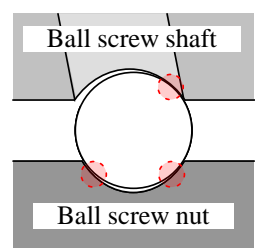

(3) Backward

Fig. 5 Change of contact points between balls and grooves of ball screws at reversal motion 
し，摩擦特性が 2 段のステップ状に変動したことが考えられる.

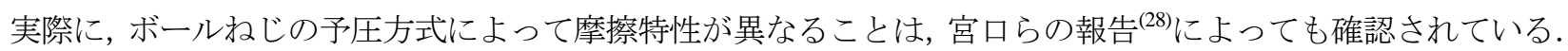
具体的には, オーバサイズボール予圧方式とダブルナット予圧方式の駆動機構で, 運動方向反転後のボールねじ 内部のボールの挙動について示しているとともに，反転後の摩擦トルクをそれぞれ測定し，図 6 に示すように予 圧方式によって摩擦特性が変化することを明らかにしている．ダブルナット予圧方式は，2 つのナット間に間座 を挟むことによってねじ軸の溝のピッチに対してナットの溝のピッチを一部変えて予圧を与えるものであり，才 フセット予圧方式と同様の方式である，そのため，本論文でのオーバサイズボール予圧方式とオフセット予圧方 式における摩擦特性の違いは, 宮口らの報告と同様に, 各予圧方式のボールねじ内部のボールの挙動に起因して 内部機構の摩擦が変化したことが原因であることが確認できる.

したがって，ボールねじの予圧方式の摩擦特性に応じて 1 山や 2 山の突起形状をもった象限突起が形成された 原因は, 各予圧方式に起因してボールねじ内部の挙動が変化するに伴い, 摩擦特性も変化したためと考えられる.

\section{4. ボールねじの予圧方式に対応した摩擦モデルおよび補償器}

\section{$4 \cdot 1$ 象限突起の形状と摩擦モデル}

さらに，摩擦特性が象限突起に及ぼす影響を検証するため，実験装置のシミュレーションモデルを使って各摩 擦特性における象限突起の形状を調査した。本論文では，まずオーバサイズボール予圧方式の摩擦特性を式(1)で モデル化した.

$$
f_{\text {oversized }}=f_{c}\left\{2 \tanh \left(a \theta_{r}\right)-1\right\} \operatorname{sgn}(\dot{\theta})
$$

また，オフセット予圧方式では，運動方向反転後にボールねじ内部の接触点数が 2 点から 3 点に変化するまでに 移動したテーブル変位をフリーゾーンとし，オフセット予圧方式の摩擦特性を式(2)〜(3)でモデル化した.

$$
\begin{array}{ll}
\left(x_{r}<F\right) \text { のとき } & f_{\text {offset }}=f_{c 1}\left\{2 \tanh \left(a_{1} \theta_{r}\right)-1\right\} \operatorname{sgn}(\dot{\theta})-f_{c 2} \operatorname{sgn}(\dot{\theta}) \\
\left(x_{r} \geq F\right) \text { のとき } & f_{\text {offset }}=f_{c 1}\left\{2 \tanh \left(a_{1} \theta_{r}\right)-1\right\} \operatorname{sgn}(\dot{\theta})+f_{c 2}\left\{2 \tanh \left(a_{2}\left(\theta_{r}-F\right)\right)-1\right\} \operatorname{sgn}(\dot{\theta})
\end{array}
$$

ここで， $f_{c}, f_{c 1}, f_{c 2}$ はクーロン摩擦トルク $[\mathrm{Nm}], \theta_{r}$ は運動方向反転位置からのテーブル変位に対応したモ 一夕回転角度[rad]， $a ， a_{1}, a_{2}$ は運動方向反転後の摩擦卜ルクの立ち上がりを決定する定数であり， $F$ はフリー ゾーンをボールねじ定数によってモータ回転角度に換算した值[rad]である.これらの補償パラメータは, 実験結 果（図 4）からヒステリシスループに近似するように試行錯誤的に同定している.

これらの摩擦モデルを実験装置のシミュレーションモデルに組み込み, 前章と同様に, 送り速度 $0.01 \mathrm{~m} / \mathrm{min}$, 指令半径 $100 \mu \mathrm{m}$ の低速円運動によって摩擦特性を, シミュレーションにより求めた. シミュレーションによっ て得られたテーブル変位とモータトルクの関係を図 7 に破線で示す．同図には寸でに図 4 に示した実験結果も会 わせて示す，図によると，摩擦モデルによってオーバサイズボール予圧方式では 1 段，オフセット予圧方式では 2 段のヒステリシスループを再現できており，特に摩擦特性の立ち上がり部分をよく再現できている.

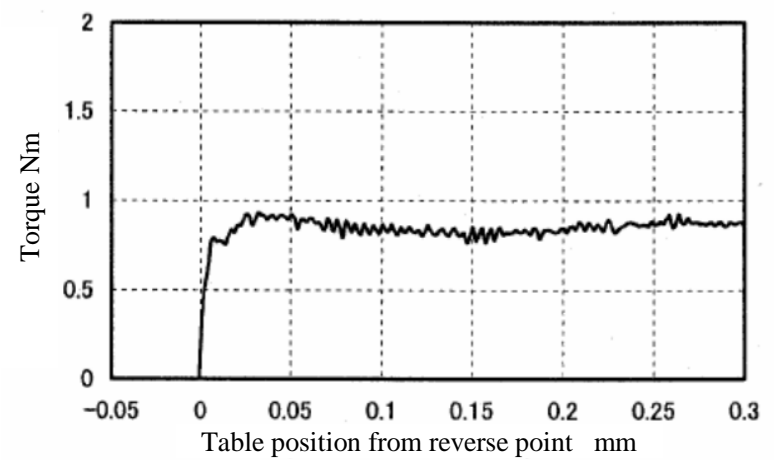

(a) Oversized ball preloaded ball screw

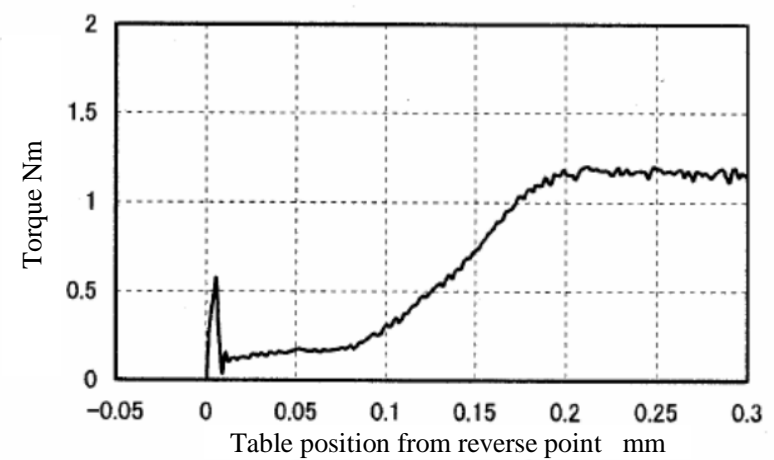

(b) Offset preloaded ball screw

Fig. 6 Friction torque after reversal the direction measured by Miyaguchi (28) (feed rate: $1 \mathrm{~mm} / \mathrm{min}$ ) 


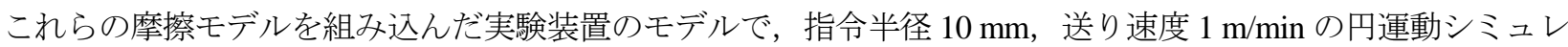
ーションを行った. 図 8 にシミュレーション結果を示す. 図によると, オーバサイズボール予圧方式とオフセッ 卜予圧方式それぞれの摩擦モデルによって 1 山と 2 山の象限突起を再現できることがわかった。また，シミュレ ーションと実験の結果（図 3) と比較すると, 各予圧方式の 1 山または 2 山の象限突起の突起形状をよく再現で きていることが確認できる.

このことから，象限突起の形状は摩擦特性に起因し，摩擦特性が 1 段または 2 段のヒステリシスループとなる ことによって象限突起も 1 山または 2 山になることがわかった.

\section{$4 \cdot 2$ 摩擦補償器とその効果}

本論文では，オフセット予圧方式に生じる 2 山の象限突起を補正するため，摩擦モデルを使って摩擦の影響を 打ち消す補償器を開発した。この補償器を摩擦補償器と呼ぶことにする。摩擦補償器の構成は, 図 9 に示すよう に, テーブル指令值 $x_{r e f}[\mathrm{~m}]$ から変位推定器を介して推定テーブル変位 $\hat{x}[\mathrm{~m}]$ を算出し, 推定モ一タ回転角度 $\hat{\theta}$ $[\mathrm{rad}]$ 入変換する. そして, 摩擦モデルによって推定モータ回転角度 $\hat{\theta}$ から駆動機構の推定摩擦卜ルク $f_{c}$ を求め, サーボ系の応答遅れを補償し，トルク信号に変換してトルク補償信号 $T_{c}$ を出力する. 摩擦補償器では，図に示す ように，駆動機構の総摩擦トルクを推定したトルク補償信号 $T_{c}$ を制御器から出力されるトルク指令 $T_{r e f}$ に印加す ることで，駆動機構内に発生する摩擦の影響を打ち消して象限突起を補正する. なお，摩擦モデルのパラメータ は実験結果（図 4）で試行錯誤的に同定したものを用いている.

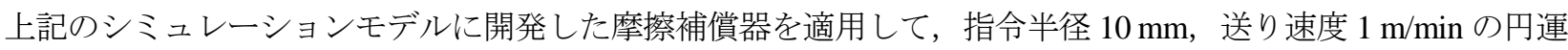
動をシミュレーションした. 図 10 に補償器を適用しない場合と適用した場合のシミュレーション結果を示す.ま た, 摩擦補償器と従来の補償方法とを比較するため, 式(1)のみを使った従来の補償器(22)を適用した場合について も同図に示す。図によると，従来の補償器では象限突起の 1 山目のみ抑制できることに対し，摩擦補償器の適用 によって象限突起の 2 山がそれぞれ $1 \mu \mathrm{m}$ 以下に抑制されており, 開発した摩擦補償器によって的確に 2 山の象 限突起を補正できることがわかった，さらに，高速円運動時での摩擦補償器の効果についても調べるため，指令 半径 $10 \mathrm{~mm}$, 送り速度 $9 \mathrm{~m} / \mathrm{min}$ で円運動のシミュレーションを行った. シミュレーション結果を図 11 に示す. 図 によると, 補償器がない場合では象限突起が大きく現れてしまうが, 補償器を適用した場合では象限突起が $2 \mu \mathrm{m}$ 程度に抑制されており，高速円運動でも摩擦補償器によって象限突起を大幅に補正できることがわかった.

そこで，実際に摩擦補償器を実験装置に組み込んで，シミュレーションと同様に，指令半径を $10 \mathrm{~mm}$ として送 り速度を $1 \mathrm{~m} / \mathrm{min} と 9 \mathrm{~m} / \mathrm{min}$ の円運動を行った。実験結果を図 12 に示す。また，補償器を適用しない場合の実験 結果も重ねて同図に示す.図によると, 送り速度 $1 \mathrm{~m} / \mathrm{min}$ の場合では摩擦補償器を適用することによって $\mathrm{Y}$ 軸 90 の位置で象限突起高さは $14.8 \mu \mathrm{m}$ から $2.2 \mu \mathrm{m}$ に, 送り速度 $9 \mathrm{~m} / \mathrm{min}$ の場合では $23.6 \mu \mathrm{m}$ から $6.1 \mu \mathrm{m}$ に抑制されて いる.よって，高速円運動では摩擦補償器の効果が低下するものの，それぞれの送り速度において象限突起が大

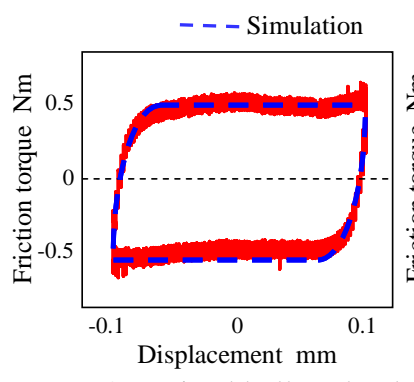

(a) Oversized ball preload

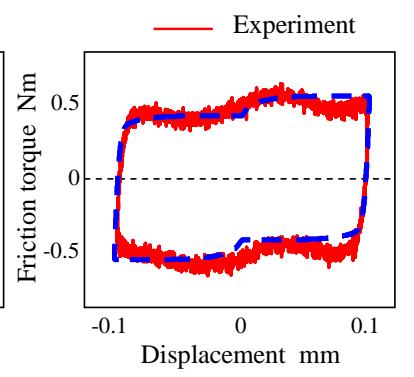

(b) Offset preload

Fig. 7 Simulation results of friction torque

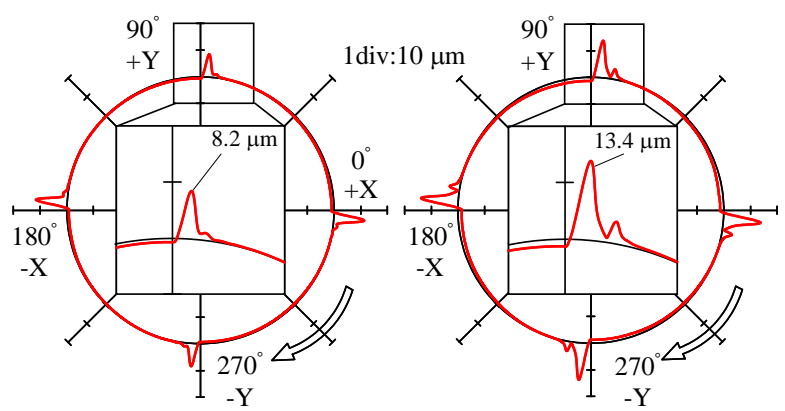

(a) Oversized ball preload

(b) Offset preload

Fig.8 Simulation results of circular motions with friction model (radius: $10 \mathrm{~mm}$, feed rate: $1 \mathrm{~m} / \mathrm{min}$ )

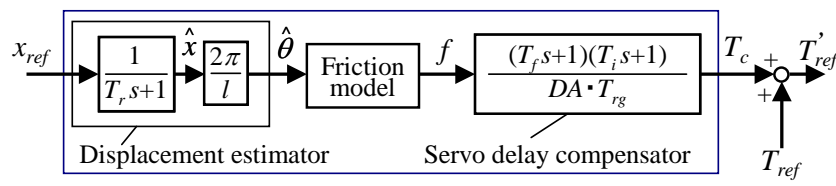

Fig. 9 Detail of friction compensator 
幅に低減されており，実験でもシミュレーションと同様に，送り速度が変わっても 2 山の象限突起を高精度に補 正できることがわかった．また，テーブルの各軸に設けたリニアエンコーダでも，同様に補償効果が得られるこ とは確認できている. したがって, 開発した摩擦補償器が 2 山の象限突起の補正に有効であることが確認できた.

\section{5. 摩擦補償器の実機への実装}

\section{$5 \cdot 1$ 実装した摩擦補償器の効果}

さらに本論文では，オフセット予圧方式のボールねじを組み込んだ直進 3 軸のマシニングセンタにも摩擦補償 器を適用し, 補償器の実用化について検討した。 まず摩擦補償器を実装するにあたり, 実験装置と同様の低速円 運動によって摩擦特性を測定した. 実機での摩擦特性の測定結果を図 13 に実線で示す.さらに, その測定結果に 基づいて摩擦モデルを同定した，その同定結果についても同図に破線で示寸．図の測定結果を見ると，実機の摩 擦特性は実験装置よりもヒステリシスループのステップ形状が明確に現れており，実機でも摩擦特性が 2 段のス テップ状を示すことがわかった，また，図より，実機用に補償パラメータを同定することによって，摩擦モデル で実機の摩擦特性をよく再現できていることが確認できた.

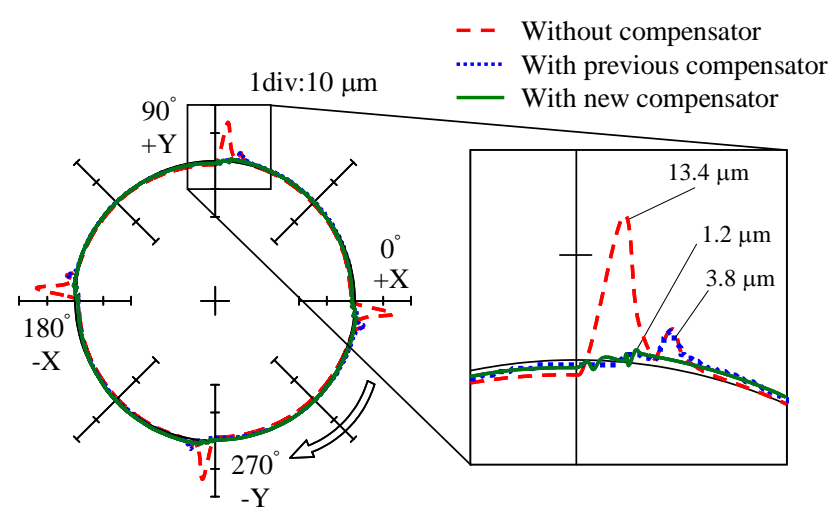

Fig. 10 Effect of the compensator in simulation (radius: $10 \mathrm{~mm}$, feed rate: $1 \mathrm{~m} / \mathrm{min}$ )

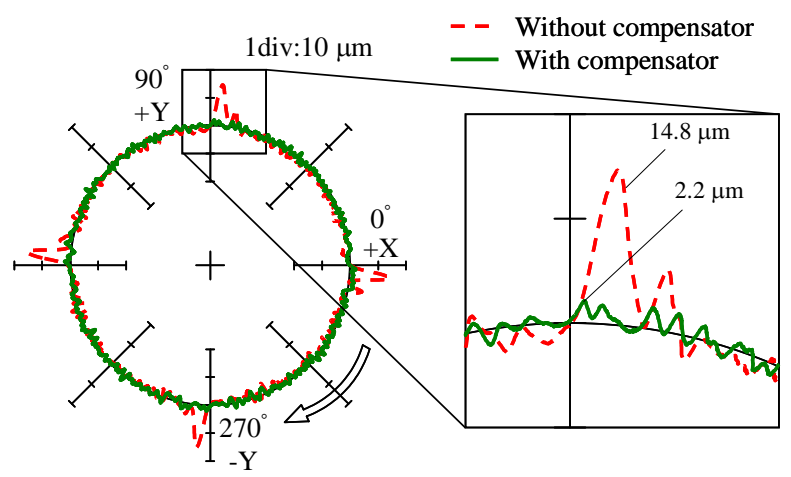

(a) Radius: $10 \mathrm{~mm}$, Feed rate: $1 \mathrm{~m} / \mathrm{min}$

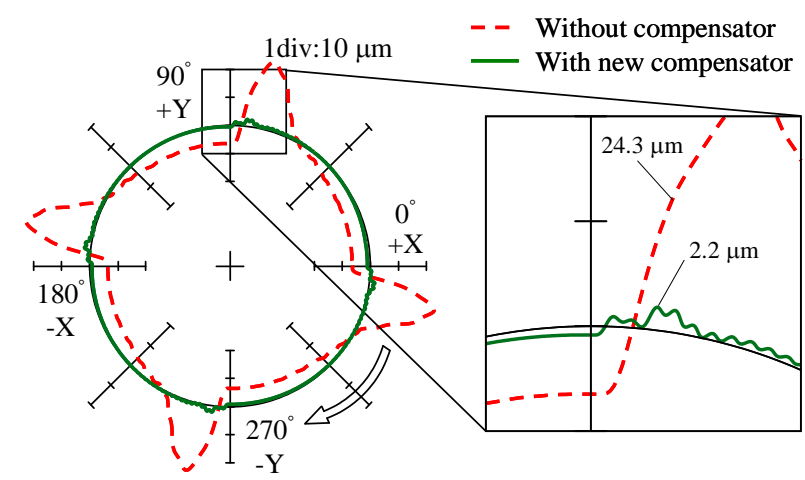

Fig. 11 Effect of the compensator in simulation (radius: $10 \mathrm{~mm}$, feed rate: $9 \mathrm{~m} / \mathrm{min}$ )

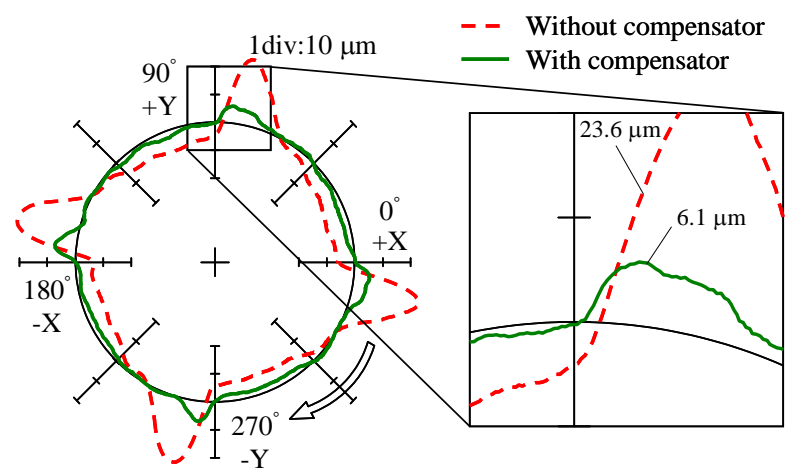

(b) Radius: $10 \mathrm{~mm}$, Feed rate: $9 \mathrm{~m} / \mathrm{min}$

Fig. 12 Effect of the compensator in experiments

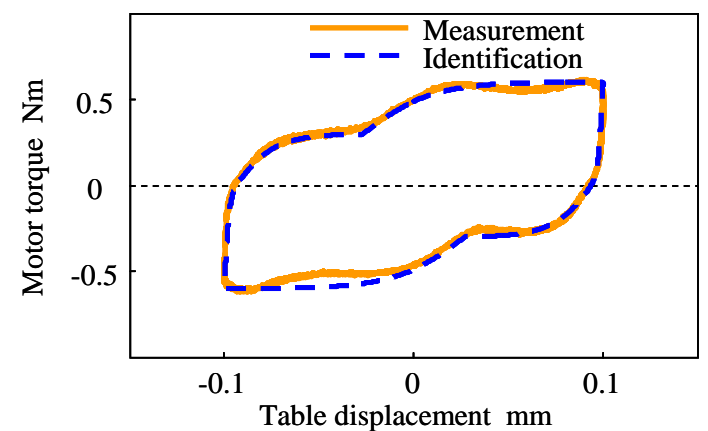

Fig. 13 Hysteresis loop of motor torque for friction model 
そこで，この摩擦モデルに基づいて実機用の摩擦補償器を構築し，実機で補償器の実装効果を検証した。この とき, 送り速度に対して補償器のモデル誤差が小さい送り速度 $3.16 \mathrm{~m} / \mathrm{min}$ の円運動で, 摩擦補償器の補償パラメ 一夕を象限突起が十分に補正できるように試行錯誤的に調整し, 補償器が広範囲の送り速度でも対応できるよう に補償パラメータの再設定をしている. 実機に補償器を組み込んで, 指令半径 $10 \mathrm{~mm}$ として, 送り速度 $3.16 \mathrm{~m} / \mathrm{min}$ と $10 \mathrm{~m} / \mathrm{min}$ の円運動を行った．補償器を適用した場合と適用しない場合の結果を併せて図 14 に示す. 図による と, 送り速度 $3.16 \mathrm{~m} / \mathrm{min}$ では補償器をしない場合では 2 山の象限突起の 1 山目が $7.0 \mu \mathrm{m}, 2$ 山目が $6.5 \mu \mathrm{m}$ となっ ている. また, 補償器を適用すると, 2 山の象限突起はそれぞれ $2.0 \mu \mathrm{m}$ 以下となっており, 運動軌跡にモデル誤 差の影響がわずかに現われているものの，象限突起を高精度に補正できたことが確認できる．また，送り速度 10 $\mathrm{m} / \mathrm{min}$ でも補償器の効果によって象限突起高さが $7.0 \mu \mathrm{m}$ から $2.0 \mu \mathrm{m}$ 以下にとなり, 同様に 2 山の象限突起を大 幅に補正されたことも確認できる，以上の結果から，送り速度が変化しても，摩擦補償器によって象限突起を高 精度に補正できることがわかった。

\section{$5 \cdot 2$ 円運動の位置の影響}

実際の加工ではテーブル駆動範囲内の一ヶ所だけで全ての加工を行うことはないため, テーブルの運動位置に よって補償効果にどのような影響が現れるかを調べた. 円運動は指令半径 $10 \mathrm{~mm}$, 送り速度 $3.16 \mathrm{~m} / \mathrm{min}$ として, 円運動の開始位置を X 軸, $\mathrm{Y}$ 軸それぞれの方向に $\pm 20 \mathrm{~mm}$ 移動させて補償器を実装した. 図 15 に 軸方向移動 させたときの実験結果，図 16 に Y 軸方向に移動させたときの実験結果を示す. 図 15 によると，X軸方向に円運 動開始位置を移動させても, 補正後の象限突起高さはX 軸 $180^{\circ}$ の位置, $\mathrm{Y}$ 軸 $90^{\circ}$ の位置のどちらも約 $1 \mu \mathrm{m}$ に抑 制されている，さらに，図 16 の $\mathrm{Y}$ 軸方向を移動させた場合でも，X軸と同様に，補正後の象限突起高さは $1 \mu \mathrm{m}$ 程度となっていることがわかる. したがって, 円運動の位置が変わっても, 摩擦補償器によって 2 山の象限突起 を高精度に補正できることがわかった。

\section{$5 \cdot 3$ 負荷質量の影響}

テーブル上に工作物が載っている状態を想定し, テーブル上に負荷質量を取り付けて摩擦補償器の補償効果を 調查した. 実機のテーブル上には, $100 \mathrm{~kg}$ と $200 \mathrm{~kg}$ の負荷質量をそれぞれ取り付け, 摩擦補償器を適用して指令

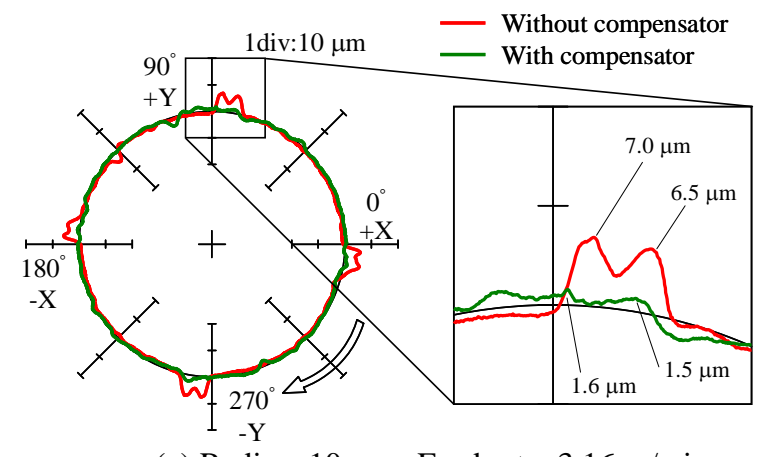

(a) Radius: $10 \mathrm{~mm}$, Feed rate: $3.16 \mathrm{~m} / \mathrm{min}$

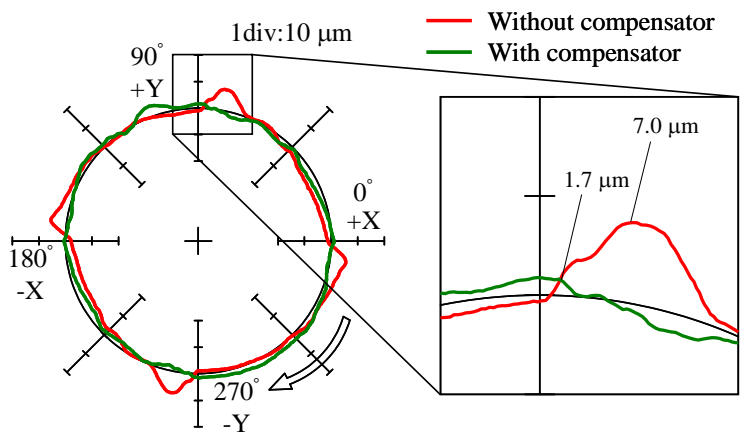

(b) Radius: $10 \mathrm{~mm}$, Feed rate: $10 \mathrm{~m} / \mathrm{min}$

Fig. 14 Effect of the compensator implemented in a real MC

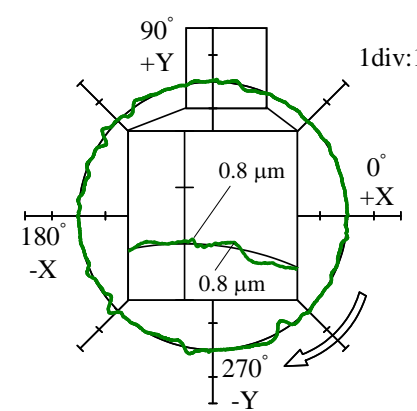

(a) Position at $-20 \mathrm{~mm}$

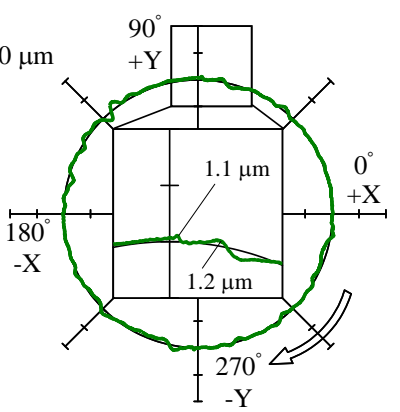

(b) Position at $+20 \mathrm{~mm}$

Fig. 15 Effect of positions of circular motions in $\mathrm{X}$-axis direction

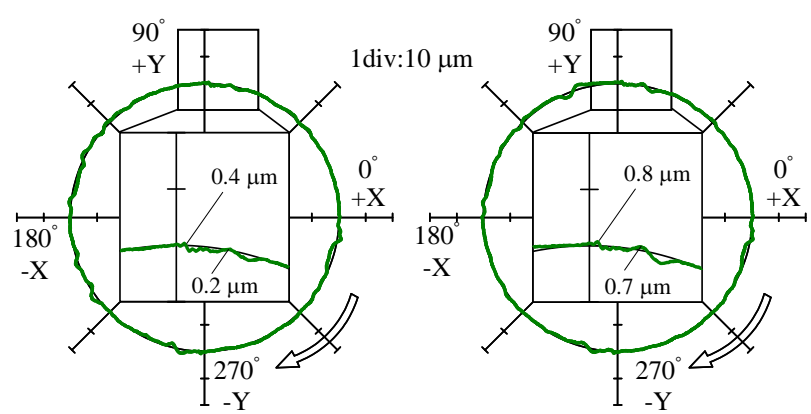

(a) Position at $-20 \mathrm{~mm}$

(b) Position at $+20 \mathrm{~mm}$

Fig. 16 Effect of positions of circular motions in Y-axis direction 


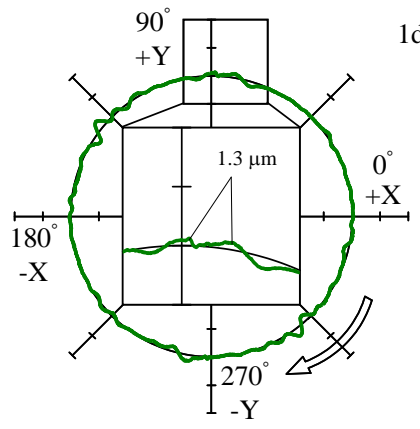

(a) Mass: $100 \mathrm{~kg}$

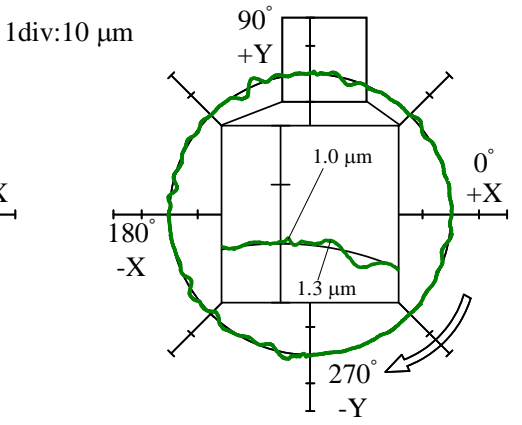

(b) Mass: $200 \mathrm{~kg}$

Fig. 17 Effect of mass on the compensation results

半径 $10 \mathrm{~mm}$, 送り速度 $3.16 \mathrm{~m} / \mathrm{min}$ の円運動を行った. 図 17 にその実験結果を示寸. 図によると, 負荷質量が 100 $\mathrm{kg}$ と $200 \mathrm{~kg}$ との両方の場合で，負荷質量を積載しない場合（図 14(a)）と同様に，2山の象限突起を約 $1 \mu \mathrm{m}$ に補 正できていることが確認できる，したがって，摩擦補償器は，負荷質量をテーブルに積載した場合でも補償効果 は低下せず，テーブルに積載しない場合と同様に 2 山の象限突起を高精度に補正できることがわかった。

\section{6. 結 言}

本論文では，ボールねじの予圧方式によって象限突起形状が変化し，その原因が摩擦特性の変化による影響で あることを明らかにした，そして，オフセット予圧方式について摩擦特性をモデル化し，そのモデルに基づいた 摩擦補償器を開発し，補償器の効果を実証した，得られた主な結論は，次のようになる。

(1) オーバサイズ予圧方式では 1 段, オフセット予圧方式では 2 段のステップ状の摩擦特性を示し, 象限突起が 摩擦特性に起因して 1 山，2 山の突起形状が形成される.

(2) 開発した補償器は, 摩擦モデルを使って摩擦特性を同定することで, 実験装置だけでなく, マシニングセン タでも 2 山の象限突起を高精度に補正できる．また，円運動の送り速度を変化させても，象限突起を高精度 に補正できる。

（3）補償器の実用場面を想定して, 円運動の開始位置を変えた場合でも, 摩擦補償器によって象限突起の補正が 可能である. さらに, テーブル上に負荷質量の積載した場合でも, 補償器によって象限突起を高精度に補正 できる.

開発した補償器は, 内部に摩擦モデルを有しており, 摩擦モデルのパラメータの同定を試行錯誤的に行った. そのため，今後はパラメータの自動同定方法を検討する必要がある．また，実用場面をさらに想定すると，ボー ル㸚じの摩耗によって予圧が低くなると，摩擦特性が変化し，象限突起に補正できなくなってしまうことが考え られるため, 予圧が低くなっても象限突起を補正できる補償器の開発が必要となってくる.

\section{文献}

(1) JIS B 6190-4: 工作機械試験方法通則一第 4 部：数值制御による円運動試験，日本規格協会, (2008).

（2）松原厚, 精密位置決め・送り系設計のための制御工学, 森北出版, (2008), pp. 188-191.

(3) 岩崎誠, 柴田知宏, 松井信行, “外乱オブザーバによる非線形摩擦補償とテーブル駆動系への適用”, 電気学会論文 集(D 編), Vol.118, No.1, (1998),pp. 51-57.

（4）海野徹, 森本喜隆，市田良夫，佐藤隆之介，“工作機械の送りテーブルの実時間動特性計測とそれに基づく軌跡制 御” , 精密工学会誌, Vol.74, No. 1, (2008), pp.72-76.

(5) Mei, X., Tsutsumi, M., Tao, T., and Sun, Y, "Study on the Compensation of Error by Stick-slip for High-precision table", International Journal of Machine Tools \& Manufacture, Vol. 44, No. 5, (2004), pp. 503-510.

(6) Jamaludin, Z., van Brussel H., and Swevers,J., "Tracking Performances of Cascade and Sliding Mode Controllers with Application to a XY Milling Table”, Proceedings of ISMA2006, (2006), pp. 81-91. 
(7) 長島一男, 勝木雅英, 河上邦治, “NC 工作機械の象限切替え突起量の理論解析と入力適応系による補正”, 日本機 械学会論文集 C 編, Vol. 66, No. 648, (2000), pp. 2877-2883.

(8) 坦野義昭, 井原之敏, 中津喜夫, 篠原章翁, “NC 工作機械の運動精度に関寸る研究(第 6 報)”, 精密工学会誌, Vol. 56, No. 4, (1990), pp. 739-744.

（9）杉江弘, 岩崎隆至, 中川秀夫, 幸田盛堂, “外乱オブザーバを用いた適応型ロストモーション補正” , 日本機械学会 論文集 C 編, Vol. 74, Vol. 739, (2008), pp. 619-625.

(10) 岩下平輔, フルクローズド・ループ方式における象限突起補正方法, 日本国特許第 3129622 号 (2004).

(11) 岩下平輔, 河村宏之, 湯志, サーボモータ駆動制御装置, 日本国特許第 3805309 (2004).

(12) 加藤哲朗, 畑中心, サーボモータの制御方式, 日本国公開特許公報, 特開平 7-281758 (1995).

(13) 村田健一, 突起補償方法および突起補償つきモータ制御装置, 日本国公開特許公報, 特開 2000-10612 (2000).

(14) 前田佳弘, 岩崎誠, “転がり摩擦モデルに基づく外乱オブザーバの始動時摩擦補償”, 電気学会論文誌 D 編, Vol. 130, No. 2, (2010), pp. 228-235.

(15) 海野徹, 森本喜隆, 市田良夫, 佐藤隆之介, “摩擦モデルによる象限突起補正と実時間逆伝達関数制御を併用した円 弧補間加工”，先端加工, Vol. 26, No. 1, (2008), pp. 33-38.

(16) Park, E.-C., Lim H., and Choi, C.-H., "Position Control of X-Y Table at Velocity Reversal Using Presliding Friction Characteristics” , IEEE Transactions on Control Systems Technology, Vol. 11, No. 1 (2003), pp. 24-30.

(17) Erkorkmaz, K., and Altintas, T., "High Speed CNC System Design. Part II, Modeling and Identification of Feed Drives” , International Journal of Machine Tools \& Manufacture, Vol. 41, (2001), pp. 1487-1509.

(18) Canudas de Wit,C., Olsson,H., Åstrom,K. J., and Lischinsky,P., “A New Model for Control of Systems with Friction” , IEEE Transactions on Automatic Control, Vol. 40, No. 3, (1995), pp. 419-425.

(19) 杉江弘, 岩崎隆至, 中川秀夫, 幸田盛堂, “工作機械における位置変動ロストモーションのモデル化と補償” , 日本 機械学会論文集 C 編, Vol. 73, No. 733, (2007), pp. 2434-2440.

(20) 山崎敬則, 瀬戸将城, 堤正臣, “数值制御工作機械送り駆動系の摩擦補償器の設計” , 精密工学会誌, Vol. 66, No. 11, (2000), pp. 1781-1785.

(21) Suzuki, Y., Matsubara, A., Kakino, Y., and Tsutsui,K., “A Stick Motion Compensation System with a Dynamic Model” , JSME International Journal, Series C, Vol. 47, No. 1, (2004), 168-174.

(22) 佐藤隆太, 寺島義道, 堤正臣, “微小変位領域の摩擦特性を考慮した象限突起補償器”, 精密工学会誌, Vol. 74, No. 6, (2008), pp. 622-626.

(23) 岩崎誠, 柴田知宏, 松井信行, “テーブル駆動系における GMDH による非線形摩擦の自律モデリングと補償”, 電 気学会論文誌 C 編, Vol. 120, No. 1, (2000), pp. 20-26.

(24) 藤田純, 濱村実, 斯波和広, 坦野義昭, 松原厚, 大脇悟史, “NC 工作機械の象限切替時運動誤差に与える案内機構の 影響” , 精密工学会誌, Vol. 68, No. 3, (2002), pp. 435-440.

(25) 佐藤隆太, 堤正臣, “AC サーボモータと直動転がり案内を用いた送り駆動系の数学モデル”, 精密工学会誌, Vol. 71, No. 5, (2000), pp. 633-638.

(26) 佐藤隆太, 堤正臣, 長島一男, “円運動象限切り替え時における送り駆動系の動的挙動”, 精密工学会誌論文集, Vol. 72, No. 2, (2006), pp. 208-213.

(27) Hsieh, C., and Pan, Y.-C., “Dynamic Behavior and Modeling of the Pre-sliding Static Friction”, Wear, Vol. 242, No. 1, (2000), pp. 1-17.

(28) 宮口和男, 二宮瑞穂, 渡辺靖巳, 新井覚, 浜村実, 垣野義昭, “ボールねじ運動方向反転時の摩擦トルク変動に関す る研究(第 1 報)”, 精密工学会誌, Vol. 68, No.6, (2002), pp. 833-837.

(29) 濱村実, 藤田純, 宮口和男, 渡辺靖巳, 垣野義昭, 松原厚, “ボールねじ運動方向反転時の摩擦卜ルク变動に関する 研究(第 2 報)”，精密工学会誌, Vol. 69, No. 5, (2003), pp. 726-730. 